\title{
THE RELATIONSHIP BETWEEN PRODUCTION AND CONSUMPTION OF ALCOHOL AND ITS TAXATION IN THE EU COUNTRIES
}

\author{
Petr David ${ }^{1}$, Lucie Formanová1, Adam Lisický ${ }^{1}$, Kristýna Torkošová1, \\ Michaela Vetráková ${ }^{1}$
}

\footnotetext{
${ }^{1}$ Department of Accounting and Taxes, Faculty of Business and Economics, Mendel University in Brno, Zemědělská 1, 61300 Brno, Czech Republic
}

Link to this article: https://doi.org/10.11118/actaun202068030597

Received: 13. 6. 2018, Accepted: 1. 6. 2020

To cite this article: DAVID PETR, FORMANOVÁ LUCIE, LISICKÝ ADAM, TORKOŠOVÁ KRISTÝNA, VETRÁKOVÁ MICHAELA. 2020. The Relationship Between Production and Consumption of Alcohol and its Taxation in the EU Countries. Acta Universitatis Agriculturae et Silviculturae Mendelianae Brunensis, 68(3): 597-604.

\begin{abstract}
The taxation of alcoholic beverages in the EU member states varies despite the harmonization efforts. This situation has been caused by the relatively liberal tendencies in tax policies concerning the determination of excise duties on alcohol and alcoholic products. The main goal of the present research is to identify the relationship between the taxation of spirits, beer and wine on the one hand, and the production and consumption on the other hand. This dependence is examined through the correlation analysis of the degree of taxation and production/consumption. The highest values of negative correlation have been identified between the taxation and consumption/production of wine. The correlation suggests that tax aspects influence both the production and the consumption of wine. Lower values of correlation coefficients between the production/consumption and taxation of beer and spirits show that these taxes represent stable and well predictable revenues of the EU member states' budgets. The obtained results support the significance of fiscal function of these taxes. Thus, there is a contradiction between the main function of excise duties and the real state of affairs in the area of taxes on the consumption of alcohol and alcoholic beverages. These are facts to be considered in the future efforts to harmonize excise duties.
\end{abstract}

Keywords: alcohol, taxation, fiscal effect, consumption, production

\section{INTRODUCTION}

Excise duties in all developed economic systems represent a fiscal and political instrument of indirect taxation which is incorporated into the prices of goods and services by retailers. Excise duties may turn into an obstacle to free trade among the EU countries, and therefore selected excise duties are harmonized in the EU member states. Through the introduction of an excise tax on a certain commodity type, the state is able to regulate the market price of such commodities, and it may also use such tax as an instrument to reduce harmful consumption. On the other hand, the receipt from excise taxes is an important state budget revenue (provided that the commodities that are subject to taxation cannot be substituted with other products).

The goal of the article is to identify the relationship between the production/consumption and tax rate for spirits, wine and beer in the EU countries. The analysis examines the data concerning the following alcoholic products: spirit, beer and wine. The correlation analysis is applied to verify the above mentioned relationship; its outcome is a correlation coefficient, which expresses the degree of dependence of the examined variables. The sense of the research is to verify the correlation 
of the variables and to ascertain whether there is a dependence between the production/ consumption and the rate of a particular excise tax (fiscal effect of taxation) or whether there is no such relationship. The results obtained will enable determining whether the EU member states maintain a lower tax burden for goods which are preferred by consumers.

\section{Literature Review}

The consumption of alcoholic products can be considered as a serious social problem in the European Union countries. The recent studies characterize the European Union as a region with the highest alcohol consumption in the world (Anderson et al., 2012; Sopek, 2013). Therefore, there are efforts to use excise tax rates as a regulatory mechanism. The main issue of taxation of alcoholic beverages and their consumption in the EU countries is addressed by Directive 92/84/EEC (European Commission, 1992a). This directive states that countries whose tax rate imposed on spirits is between 550-1000 euro/hl of ethanol cannot reduce this rate. At the same time, countries which use higher tax rates than 1000 euro cannot reduce the rate below 1000 euro. Furthermore, the directive allows individual countries of the EU to implement a reduced tax rate for small producers with annual production of up to $10 \mathrm{hl}$ of pure alcohol. However, the reduced tax rate must not be less than $50 \%$ of the standard national rate. As a very important directive for tax harmonization efforts concerning beer, Directive 92/83/EEC (European Commission, 1992) can be considered. This directive defines the possibility of applying tax zones according to an annual production of brewers. Furthermore, the above mentioned Directive 92/84/EEC deals with the approximation of excise duty on alcohol and alcoholic beverages. The minimum tax rate for beer is defined by two different ways. Firstly, the minimum tax rate for beer is defined as 0.748 euro per hectolitre/degree Plato, or secondly as 1.87 euro per hectolitre/degree of alcohol. The fundamental directives for excise duty on wine are Directive 92/83/EEC and Directive 92/84/EEC. Directive 92/84/ EEC states the minimal rate for wine, sparkling wine and other fermented drinks in the amount of 0 euro per hectolitre. Corlett and Hague (1953) focused on taxation of commodities which are related to leisure time. In their opinion, the tax rates for these products should be higher than those for other commodities. Alcohol is considered as a complement to leisure time, and therefore the above mentioned principle should apply. In all developed countries, excise duty is mainly used as a fiscal-policy instrument of generating tax revenues into the state budget. Simultaneously, it can be used as an instrument to regulate consumption (Nerudová, 2014). Fidler et al. (2015) also state that the primary purpose of excise duty on spirits is to generate revenues into the state budget and regulate harmful consumption of alcohol. However, Šafránek (2016) as well as Trasberg (2015) state two fundamental reasons for taxation of selected types of goods and services. As the first reason it is possible to mention a decrease in negative externalities and a discouragement of consumers from socially undesirable consumption. The second reason consists in raising funds for public budgets. Which of above mentioned reasons is dominant, depends on the demand for alcohol and on whether the demand is elastic; see Cnossen (2007), Rabinovich et al. (2012) or Chaloupka et al. (2002), or non-elastic and regressive especially for low-income groups, see Šafránek (2016), Kubátová (2015) or Trasberg (2015). The studies conducted by Meier et al. (2016) confirmed the existence of the regulatory function of taxation. They found out that tax levied on alcohol can eliminate harmful consumption of alcoholic products, and simultaneously, it does not have any effect on low consumption that is considered as harmless. Furthermore, the regulatory function of excise duty was confirmed by Grossman et al. (1994) in the case of young people. The sensitivity of consumption to the level of taxation was in the long-term run confirmed by Waagenar et al. (2009) and Smith (2005). On the contrary, Cnossen (2005) points out that excise duty is an ineffective tool, which causes social losses for occasional consumers, while there is no sufficient sanction on consumers with excessive consumption of alcohol. Due to numerous differences in tax rates applied in different countries of the EU, it is evident that there is no consensus on the optimal taxation of alcohol (Sopek, 2013). This can cause the existence of cross-border demand (Berkhout et al., 2014) and the creation of unreal elasticity of demand for alcohol. Provided that the assumption of zero elasticity of demand for alcohol is accepted (which was confirmed by many of the above mentioned authors), it can also cause full shifting of the tax burden into consumer prices in the long-term run (Douglas, 2002). Based on that, it is possible to predict and analyse the effects of excise duty on alcohol in relation to its production and consumption.

The aim of this article is to analyse the association between alcohol production/consumption and tax rates (beer, wine and spirits) in the EU countries. The purpose is to verify whether there is any relationship between the variables, indicating the existence of fiscal effects of excise duty on alcoholic beverages.

\section{MATERIALS AND METHODS}

Within this examination, the indicator of tax burden was chosen, namely the rate of excise duty expressed as GDP per capita in each European Union country. The GDP data were collected from the statistical portal Eurostat (2017a). The nominal tax rates were modified after they were transferred 
to ratio indicator. Thanks to this transformation, more relevant data on tax rates can be obtained and subsequently used for mutual comparison between individual member states of the European Union. Furthermore, the data were received from "Excise Duty Tables", which are annually published by the European Commission (European Commission, 2017). The tax rates used in individual years are always related to the $1^{\text {st }}$ January of each calendar year. The development of the tax rates is presented in euro. The alcohol tax rates have some special characteristics. The tax rates for spirits are presented in euro per litre of pure alcohol, not of the final product. The possibility of reduced tax rate on spirits was not taken into the account. This is due to the non-existence of data for such production. The tax rates for still wine are presented in euro per litre of product. Due to the way the tax rates for beer are published, it was necessary to unify them. The tax rate was converted to the same unit; one degree Plato is equivalent to $0.4 \%$ alcohol by volume. The relevancy of this recalculation is evident from minimal tax rates in some European Union countries which use such conversion. Moreover, this way of recalculation is used by The Brewers of Europe (2010, 2016). For the analysis of excise duty on beer, the tax rates expressed in hectolitre/degree Plato were used. The reduced tax rates for beer could not be included into the analysis because the relevant data were not available. Further, the data including the production and consumption of various kinds of alcoholic products were used. The data regarding the production of spirits were taken from Eurostat (2017a). Annual data regarding the volume of sold production in litres of pure alcohol were used in the analysis. According to the statistical data system of Eurostat in 2005-2014, the data processing detects countries whose production is insignificant. It includes the following countries: Cyprus, Luxembourg and Malta. Despite that fact, the data of these countries are going to be examined. However, in Slovenia, the production of spirits is restricted. Therefore, this country is excluded from the analysis of spirits with the purpose to avoid the distortion of results. The source data of annual beer production in individual EU countries were collected from studies of The Brewers of Europe (2010, 2016). These studies present the consumption of beer in $1000 \mathrm{hl}$ per year. Individual statistics are created based on reports from national brewery associations and other relevant sources including Eurostat or Canadian beer industry trends. For the purpose of this article, the above mentioned rates were recalculated. The values used in the analysis are stated in litres of beer produced per year. The data of wine production were gained from statistical documents of the Wine Institute (2014). It is an international and intergovernmental organisation focussing on wines, vine, wine-based beverages, table grapes, raisins and other wine- based products. One of their activities is to compile statistics from wine areas. The data are presented in litres of final product per year. There are different methods of measuring the consumption of spirits. The most frequently used variable for international comparison is the consumption of spirits per capita, which means the amount of ethanol in litres per year consumed by every person older than 15 years. The data which record the consumption of spirits per capita are grouped together and they are taken from the official national statistics of the World Health Organization (2016).

It is clear that the production and consumption of the individual types of alcoholic products in this country will not reach identical values. Domestic production cannot be delivered to another member state or exported to third countries and thus consumed outside the territory of the Czech Republic. On the other hand, domestic consumption consists not only of domestic products, but also of products delivered from other EU member states or imported from third countries.

The length of the monitored period is significantly influenced by data availability. In the case of spirits and wine, the data from 2005 to 2014 are going to be analysed (the maximal timeline is 10 years). In the case of beer, the analysed interval is longer (13 years) along the timeline of 2003-2015. The data for Croatia were not included into the analysis due to their unavailability. This is because Croatia joined the European Union in 2013. For that reason, the country was excluded from the analysis.

Based on Trasberg (2015), the association between the above mentioned indicators will be examined through the correlation analysis, where the standard output is a correlation coefficient, which describes the degree of dependence. A general formula for calculating the correlation coefficient is:

$r_{T R, V}=\frac{\sum_{i=1}^{n}\left(T R_{i}-\overline{T R}\right) \times\left(P_{i}-\bar{P}\right)}{\sqrt{\sum_{i=1}^{n}\left(T R_{i}-\overline{T R}\right)^{2} \times \sum_{i=1}^{n}\left(P_{i}-\bar{P}\right)^{2}}}$,

where:

$T R_{i} \ldots$ is excise duty rate for $i$ measurement;

$\overline{T R}$.....is arithmetic mean of excise duty rate;

$P_{i}$.......is production of the given kind of alcohol, where $P_{i}$ is the production of spirits, production of beer and production of still wine, respectively;

$\bar{P}$........is arithmetic mean of consumption of the given kind of alcohol $\bar{P}$, where $\bar{P}$ is the production of spirits, production of beer and production of still wine, respectively;

$r_{T R, P} \ldots$ is correlation coefficient between TR and $P_{i}$.

$r_{T R, V}=\frac{\sum_{i=1}^{n}\left(T R_{i}-\overline{T R}\right) \times\left(C_{i}-\bar{C}\right)}{\sqrt{\sum_{i=1}^{n}\left(T R_{i}-\overline{T R}\right)^{2} \times \sum_{i=1}^{n}\left(C_{i}-\bar{C}\right)^{2}}}$,

$C_{i}$.......is consumption of the given kind of alcohol, where $C_{i}$ is the consumption of spirits, 
consumption of beer and consumption of still wine, respectively;

$\bar{C}$........is arithmetic mean of consumption of the given kind of alcohol $\bar{C}$, where $\bar{C}$ is the consumption of spirits, consumption of beer and consumption of still wine, respectively; $r_{T R, C}$...is correlation coefficient between $T R$ and $C_{i}$.

The correlation coefficient can range from -1 to 1 . The value minus 1 indicates the strongest negative correlation, and the value plus 1 expresses the strongest positive correlation between the variables. If the value of correlation coefficient is zero, then there is no statistically significant linear relationship. Thanks to the correlation analysis it can be seen how strong is the relationship between the data. According to Ostertagová (2013), the values of correlation coefficient can be classified into 3 basic groups with limit values of 0.3 and 0.8 . Because of higher explanatory power, the classification by Evans (1996) is going to be used. He classified the degree of dependence based on absolute values of correlation coefficients. He divided the degree of the relationship into 5 intervals: up to 0.2 there is very weak, up to 0.4 weak, up to 0.6 moderate, up to 0.8 strong and up to 1 very strong association between the variables. After that, the t-test will be performed. Based on its results, the statistical significance of individual correlation coefficients can be found out. The hypotheses of the t-test are as follows:

$H_{0}: r=0 ; H_{1}: r \neq 0$.

The test statistics can be calculated according to the following formula:

$t=\frac{r \sqrt{n-2}}{\sqrt{1-r^{2}}}$
For the t-test interpretation it is necessary to calculate the critical values for correlation coefficients.

$W=\left(-\infty ; t_{\frac{\alpha}{2}}(n-2)\right\rangle \cup\left\langle t_{1-\frac{\alpha}{2}}(n-2) ; \infty\right)$,

where:

$W$......is critical value,

$n$........is sample size,

a........is significance level,

$r$.........is value of correlation coefficients,

t.........is test statistics.

Formula 4 states the calculation of the t-test statistics. If the final result is within the critical values (see formula 5), then the null hypothesis can be rejected. Moreover, it means that the correlation coefficient is statistically significant. The second possibility to evaluate the statistical significance of correlation coefficient is to use the $\mathrm{p}$-value. If the $\mathrm{p}$-value is below the significance level (in this case the significance level is 5\%), then the null hypothesis can be rejected. The correlation coefficient is therefore statistically significant.

\section{RESULTS}

The characteristics of descriptive statistics for production, consumption and rate of taxation, suggest that the differences of the above mentioned variables are significant. This corresponds with statements which are presented in the literature review and with current situation of excise taxation in the territory of the European Union. Despite the harmonisation effort, the rates of taxation in individual EU member states differ significantly. Furthermore, there are cultural and social differences which are caused by different natural conditions. They determine the production

I: Descriptive statistics of beer, spirits and wine

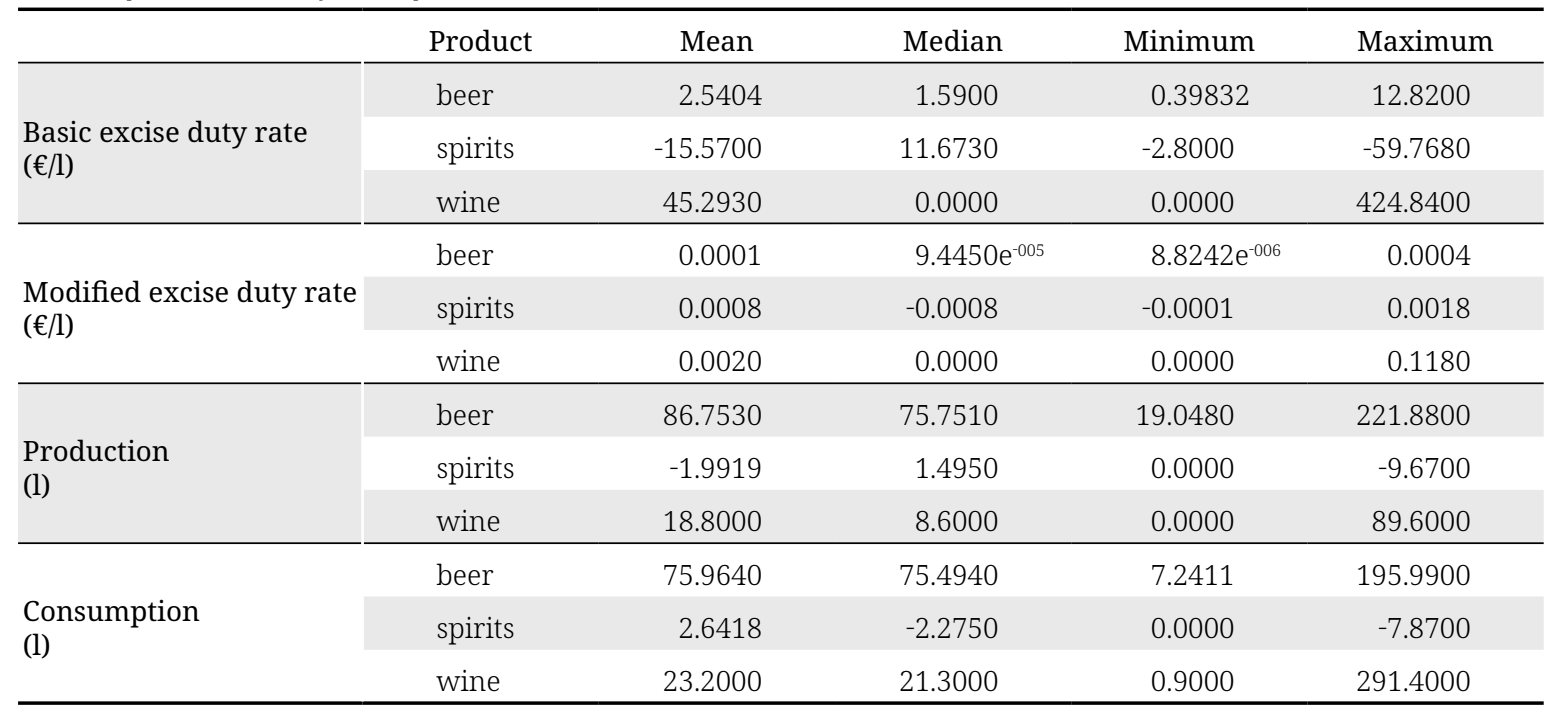

Source: own work 
II: Results of correlation analysis between production and consumption of spirits and tax rate for spirits

\begin{tabular}{lccccc}
\hline \multicolumn{1}{c}{ Variable } & $\begin{array}{c}\text { Correlation } \\
\text { coefficient }\end{array}$ & t-test & p-value & $\begin{array}{c}\text { Degree } \\
\text { of dependence }\end{array}$ & $\begin{array}{c}\text { Direction } \\
\text { of dependence }\end{array}$ \\
\hline Production & 0.2157 & 3.4780 & 0.0006 & Weak & + \\
Consumption & 0.2022 & 3.2520 & 0.0013 & Weak & + \\
Critical value of t-test & 0.1241 & Number of observations & 260 & Significance level & 0.05 \\
\hline
\end{tabular}

Source: authors

III: Results of correlation analysis between production and consumption of beer and tax rate for beer

\begin{tabular}{lccccc}
\hline \multicolumn{1}{c}{ Variable } & $\begin{array}{c}\text { Correlation } \\
\text { coefficient }\end{array}$ & t-test & p-value & $\begin{array}{c}\text { Degree } \\
\text { of dependence }\end{array}$ & $\begin{array}{c}\text { Direction } \\
\text { of dependence }\end{array}$ \\
\hline Production & 0.0024 & 0.0401 & 0.9681 & Very weak & + \\
Consumption & 0.0223 & 0.3647 & 0.7156 & Very weak & + \\
Critical value of t-test & 0.1194 & Number of observations & 270 & Significance level & 0.05 \\
\hline
\end{tabular}

Source: authors

IV: Results of correlation analysis between production and consumption of wine and tax rate for wine

\begin{tabular}{lccccc}
\hline \multicolumn{1}{c}{ Variable } & $\begin{array}{c}\text { Correlation } \\
\text { coefficient }\end{array}$ & t-test & p-value & $\begin{array}{c}\text { Degree } \\
\text { of dependence }\end{array}$ & $\begin{array}{c}\text { Direction } \\
\text { of dependence }\end{array}$ \\
\hline Production & -0.4349 & -7.9070 & $6.93 \mathrm{e}^{-014}$ & Moderate & - \\
Consumption & -0.2311 & -3.8880 & 0.0001 & Weak & - \\
Critical value of t-test & 0.1194 & Number of observations & 270 & Significance level & 0.05 \\
\hline
\end{tabular}

Source: authors

capabilities and consumer preferences. Using the data and methods presented in the methodological part of this paper, the correlation analysis for each type of alcohol (spirits, beer and wine) can be performed. The objective of the analysis is to find the association between production per capita, or consumption per capita and rate of excise tax, which is expressed as a proportion of GDP.

In the case of spirits, it is necessary to mention that there are no zero tax rates along the monitored timeline. Nominal tax rates in individual EU countries differ considerably. The difference between maximal and minimal values exceeds 57 euro per litre. Higher standard deviation in the case of production compared with consumption can indicate the existence of greater differences in production between individual EU countries and over time. The consumption of spirits is more balanced in comparison with their production, and it is also less elastic over time. The most significant producer of spirits is Ireland; the greatest consumer of spirits is Lithuania.

Furthermore, the research focused on tax rates for beer; it was found out that the values do not correspond with obligatory minimal tax rates (0.748 euro per hectolitre/degree Plato). This is caused by many exceptions, where the minimal value of the monitored timeline was 0.39832 euro per hectolitre/degree Plato. For that reason, it is not surprising that the range between maximal and minimal tax rates is enormous, specifically it is more than 12 euro per hectolitre/degree Plato. The standard deviation is higher for production than for consumption. The reason can be seen in the higher equality of consumption than the case is with production, and at the same time there is lower volatility of beer consumption than beer production over time. The most significant beer producer per capita is Ireland, followed by the Czech Republic. The values of beer consumption per capita are significantly higher in the Czech Republic

The taxation of wine can be considered as a specific part of taxation of alcoholic products in the territory of the European Union. The minimal value of excise duty on wine is 0 euro. For that reason, the individual member states can apply any tax rate. The zero tax rates are applied in most European Union countries, specifically in 16 EU countries. Therefore, the characteristics of descriptive statistics are influenced significantly. Although the other EU countries applied non-zero tax rate of up to 476 euro per hl of still wine, the value of median is 0 . The standard deviation is higher for wine production than for its consumption, but the difference is not as significant as it was in the case of previously examined alcoholic products. This points to greater stability of wine production than fluctuations in its consumption over time. There are considerable differences in wine consumption among individual EU member states; the difference is almost 42 litres 
per person/year (difference between consumption in Lithuania and France). The greatest producer of still wine per capita is Italy, followed by France. On the contrary, still wine is not produced in $6 \mathrm{EU}$ countries. Natural conditions in these countries are not favourable; these are typically countries situated in the north of Europe.

The results of the correlation analysis were calculated using formula (1 and 2). Firstly, their values can be interpreted according to the direction of dependence. The positive value (positive dependence) can indicate that the fiscal aim of excise taxation has been met. These trends are evident especially in case of production and consumption of spirits and beer. On the other hand, a negative value may point to the existence of the regulatory effect of these taxes and, as the case may be, to the possibility to give preferential treatment to domestic production and consumption. This situation was confirmed in the case of production and consumption of wine. If the degree of dependence is considered, the absolute values of correlation coefficients are relatively low; therefore, the degree of dependence varies from very weak to moderate. Very weak dependence was identified in case of beer production and consumption, weak dependence was found out for production and consumption of spirits and for consumption of wine. Further, moderate dependence was identified for wine production. The significance of correlation coefficient in the case of production and consumption of spirits and wine, respectively, was confirmed by their p-values. They are lower than the determined significance level; based on that, the null hypothesis about non-significance of correlation coefficient can be rejected. It is necessary to mention that the results for production and consumption of beer are the opposite. Using the formulas (3), (4) and (5), the t-test was performed. Based on the obtained results, except for beer production, the null hypothesis about nonsignificance of correlation coefficients was rejected. The unsatisfactory values of the t-test and p-values in case of beer might be caused by the imperfection of input data, which is caused by applying more tax rates in many EU countries or by non-existence of relevant data. Except for that, the dependence of production and consumption of beer on the tax rate is very weak; therefore, it is not appropriate to evaluate the direction of dependence or to draw any conclusion about the existence of fiscal or regulatory effects of the tax policy. In the case of spirits, the dependence of production/consumption on tax rate is weak. However, all parameters suggest that the excise duty on spirits is a tax with fiscal effects. Any form of more profound relationship was not proved, and based on the obtained results, the probability of its existence is very unlikely. Moderate dependence between the analysed variables was confirmed only in the case of still wine; moreover, the results are statistically significant. The values of correlation coefficients indicate the negative association between production or consumption and the rate of excise duty on wine. The obtained results can be interpreted in such way that there could be conditions for the existence of mutual relationship between taxation and the mentioned macro indicators and regulatory or fiscal effect in the EU countries where wine is produced or where the preference of consumption of still wine exists.

\section{CONCLUSION}

The intentional or unintentional differences in excise tax rates are a hidden form of creating unequal conditions for producers of substitutes, in this case for alcoholic beverages. Individual countries can apply alcohol taxation parameters to favour domestic producers. This situation was revealed in the case of excise duty on still wine. The conclusion drawn corresponds with findings of Anderson and Baumberg (2006). The production of wine is the most closely related to natural conditions of all alcoholic products. In the countries where the conditions for growing grapes and producing wine are favourable, the tax rates are low or zero with the aim to favour wine consumption and production of domestic producers. Similar conclusions can be formulated for wine consumption in countries where there are not only suitable conditions for wine production but also where wine is part of the culture, customs and traditions. Thanks to low or zero taxation, wine consumption is favoured over other types of alcoholic beverages.

Focusing on taxation of spirits and beer, the existence of the regulatory function and a statistically significant relationship between the tax rate and the production or consumption in the EU countries was not confirmed. The production of spirits and beer is not as related to the natural conditions as it is in the case of wine. Nevertheless, some types of spirits or beer are parts of culture, customs and traditions. However, this cannot create sufficient reasons for the existence of a strong relationship between taxation and production/consumption. On the contrary, the elements of fiscal effect were identified. It was found out that with rising production/consumption, the tax rate increases. These conclusions are consistent with Fidler et al. (2015).

Based on the obtained results, it is evident that the system of taxation is a source of advantages for domestic producers, whose activities include grape growing and wine production. As a side effect, the preference of consumption of this type of alcoholic beverage can be considered. Focusing on 
the formulation of the recommendation for the tax policy of the European Union and individual member states, it is necessary to consider the negative effects of excessive alcohol consumption on human health. Furthermore, the assumption of Cnossen (2007), Rabinovich et al. (2012) or Chaloupka et al. (2002) that taxes levied on alcoholic products can eliminate their consumption has not been confirmed. The purpose of this article is not to formulate normative conclusion or recommendation to remove regulatory or fiscal effects in individual member countries. The main objective of this contribution is to point out to the need of opening the discussion about possible harmfulness or harmlessness of the many exceptions and the large leeway in the determination of excise tax rates for alcohol. As a result of these discussions, a conclusion could be drawn, evaluating whether the current system of excise tax rates regulation in the EU countries is optimal, alternatively whether it is necessary to refine and harmonize them. Or conversely, whether the tax rates determination should be exclusively within the competency of tax policy makers in individual member states.

\section{REFERENCES}

ANDERSON, P. and BAUMBERG, B. 2006. Alcohol in Europe: A Public Health Perspective. London: Institute of Alcohol Studies.

ANDERSON, P., MOLLER, L. and GALEA, G. 2012. Alcohol in the European Union: Consumption, harm and policy approaches. Copenhagen: World Health Organisation.

BALTAGI, B. H. 2008. Econometric Analysis of Panel Data. England: John Wiley \& Sons Ltd.

BERKHOUT, B. et al. 2014. Economic effects of high excise duties on beer. Final Report. Amsterdam: Brewers of Europe. Available at: http://www.brewersofeurope.org/uploads/mycms-files/ documents/publications/2015/Report\%20on\%20Economic\%20Effects\%20of\%20High\%20 Excise\%20Duties\%20on\%20Beer.pdf [Accessed: 2018, January 19].

CHALOUPKA, F. J., GROSSMAN, M. and SAFFER, H. 2002. The effects of price on alcohol consumption and alcohol-related problems. Alcohol research and health, 26(1): 22-34.

CNOSSEN, S. 2005. Theory and practice of excise taxation: smoking, drinking, gambling, polluting, and driving. Oxford: Oxford University Press.

CNOSSEN, S. 2007. Alcohol taxation and regulation in the European Union. International Tax and Public Finance, 14(6): 699-732.

CORLETT, W. J. and HAGUE, D. C. 1953. Complementarity and the excess burden of taxation. The Review of Economic Studies, 21(1): 21-30.

DOUGLAS, J. Y. and BIELINSKA-KWAPISZ, A. 2002. Alcohol Taxes and Beverage Prices. National tax journal, 55(1): 57-73.

EUROPEAN COMMISION. 2017. Excise duties - Alcoholic beverages 2005-2014. European Commission. [Online]. Available at: https://circabc.europa.eu/faces/jsp/extension/wai/navigation/container.jsp [Accessed: 2018, January 19].

EUROPEAN COMMISSION. 1992. Council Directive 92/83/EEC of 19 October 1992 on the harmonization of the structures of excise duties on alcohol and alcoholic beverages. Available at: http://eur-lex.europa. eu/legal-content/CS/TXT/?uri=CELEX\%3A31992L0083 [Accessed: 2018, February 07].

EUROPEAN COMMISSION. 1992a. Council Directive 92/84/EEC of 19 October 1992 on approximation of the rates of excise duty on alcohol and alcoholic beverages. Available at: http://eur-lex.europa.eu/ legal-content/EN/TXT/?uri=LEGISSUM\%3Al31024 [Accessed: 2017, December 07].

EUROPEAN COMMISSION. 2017. Excise Duty on Alcohol. Europena commission. [Online]. Available at: https://ec.europa.eu/taxation_customs/business/excise-duties-alcohol-tobacco-energy/exciseduties-alcohol/excise-duties-alcoholic-beverages_en [Accessed: 2017, November 11].

EUROSTAT. 2017a. Prodcom Annual Data 2005-2014. Available at: http://ec.europa.eu/eurostat/web/ prodcom/data/excel-files-nace-rev.2 [Accessed: 2018, January 02].

EUROSTAT. 2017b. The European System of National and Regional Accounts. Available at: http:// ec.europa.eu/eurostat/web/regions/data/database [Accessed: 2017, December 10].

EVANS, J. D. 1996. Straightforward statistics for the behavioural sciences. Brooks/Cole Publishing.

FIDLER, P., IVANSKÁ, B., RAIS, J., and ROD, A. 2015. Zdanění spotreby v České republice. CETA and IPPS. Available at: http://www.politikaspolecnost.cz/wp-content/uploads/2015/03/ Zdan\%C4\%9Bn\%C3\%AD-spot\%C5\%99eby-v-\%C4\%8Cesk\%C3\%A9-republice.pdf [Accessed: 2018, February 14].

GROSSMAN, M., CHALOUPKA, F. J., SAFFER, H. and LAIXUTHAI, A. 1994. Effects of alcohol price policy on youth: a summary of economic research. Journal of Research on Adolescence, 4(2): 347-364.

KUBÁTOVÁ, K. 2015. Daňová teorie a politika. Praha: Wolters Kluwer. 
MEIER, S. et. al. 2016. Estimated Effects of Different Alcohol Taxation and Price Policies on Health Inequalities: A Mathematical Modelling Study. Plos medicine, 13(2): s1001963.

NERUDOVÁ, D. 2014. Harmonizace daňových systémů zemí Evropské unie. Praha: Wolters Kluwer.

OSTERTAGOVÁ, E. 2013. Aplikovaná štatistika. Košice: Equilibria.

RABINOVICH, L. et al. 2012. Further study on the affordability of alcoholic beverages in the EU. Rand Health Q, 2(2): 17.

ŠAFRÁNEK, L. 2016. Daně aneb cesta do otroctví? Praha: Orego.

SMITH, S. 2005. Economic Issues in alcohol taxation. In: CNOSSEN, S. (Ed.). Theory and Practice of Excise Taxation: Smoking, Drinking, Gambling, Polluting, and Driving. Oxford: Oxford University Press.

SOPEK, P. 2013. The alcohol taxation system in European Union and Croatia. Newsletter: an occasional publication of the Institute of Public Finance, 15(76): 1-14.

THE BREWERS OF EUROPE. 2010. Beer statistics: 2010 edition. Belgium: The Brewers of Europe. THE BREWERS OF EUROPE. 2016. Beer statistics: 2016 edition. Belgium: The Brewers of Europe.

TRASBERG, V. 2015. Alcohol Excise Duties in the European Union. Estonian Discussions on Economic Policy, 23(2): 1-9.

WINE INSTITUTE. 2014. World Wine Consumption by Country. Wine Institute. [Online]. Available at: http://www.wineinstitute.org/resources/statistics [Accessed: 2018, March 10].

WAGENAAR, A. C., SALOIS, M. J. and KOMRO, K. A. 2009. Effects of beverage alcohol price and tax levels on drinking: a meta-analysis of 1003 estimates from 112 studies. Addiction, 104(2): 179-190.

WORLD HEALTH ORGANISATION. 2016. Recorded alcohol per capita consumption, from 2000 Last update: May 2016. WHO. [Online]. Available at: http://apps.who.int/gho/data/view.main.52160. [Accessed: 2018, February 16].

Contact information

Petr David: david@mendelu.cz

Lucie Formanová: xformano@node.mendelu.cz

Adam Lisický: xlisicky@node.mendelu.cz

Kristýna Torkošová: xtorkoso@node.mendelu.cz

Michaela Vetráková: xvetrako@node.mendelu.cz 